\title{
Hydrogeological map of Italy: the preliminary Sheet N. 348 Antrodoco (Central Italy)
}

\section{Carta idrogeologica d'Italia: versione preliminare del Foglio N. 348 Antrodoco (Italia Centrale)}

Marco Amanti, Giovanni Conte, Lucio Martarelli, Gennaro Maria Monti, Guido Motteran, Anna Rosa Scalise, Roberto Serafini, Angelantonio Silvi

\begin{abstract}
Riassunto: Il Servizio Geologico d'Italia dell'Istituto Superiore per la Protezione e la Ricerca Ambientale sta realizzando, nell'ambito del Progetto di CARtografia Geologica e geotematica d'Italia (CARG), il Foglio N.348 Antrodoco (Italia centrale) della Carta idrogeologica d'Italia, quale sperimentazione cartografica delle linee guida nazionali per il rilevamento e la rappresentazione cartografica idrogeologica. Larea di studio è caratterizzata da unità geologicostrutturali profondamente coinvolte nell'orogenesi appenninica (Regioni Lazio e Abruzzo, Province di Rieti e L'Aquila) e comprende depositi di ambiente marino di piattaforma carbonatica, di margine, di bacino e di avanfossa che ospitano grandi quantità di risorsa idrica sotterranea. La cartografia è stata realizzata allo scopo di ottenere un'ottimale rappresentazione degli elementi idrogeologici rilevati in campagna e di caratterizzare l'assetto idrogeologico dell'area. È stata costituita una rete di controllo per la misurazione mensile delle portate idriche delle acque superficiali e sotterranee e dei relativi parametri idrogeochimici. I dati sono stati organizzati in un geographic information system che ha permesso di realizzare la presente cartografia preliminare consistente in una Carta principale basata sulla rappresentazione dei seguenti complessi idrogeologici rispetto al loro grado di permeabilità relativa (dal basso in alto): i) complesso calcareo (Giurassico-Cretacico; permeabilità alta); ii) complesso calcareo-marnoso (Cretacico superiore-Eocene medio; permeabilità media); iii) complesso marnoso-calcareo e
\end{abstract}

Parole chiave: idrogeologia; carta idrogeologica; Antrodoco; Italia Centrale.

Keywords: hydrogeology; hydrogeological map; Antrodoco; Central Italy.

\author{
Lucio MARTARELLI 垟" \\ Geological Survey of Italy \\ Italian National Institute for Environmental Protection and Research \\ via Vitaliano Brancati 48, 00144 Rome, Italy \\ Tel. +39.06.50074364. \\ lucio.martarelli@isprambiente.it \\ Marco AMANTI, Giovanni CONTE, \\ Gennaro Maria MONTI, Guido MOTTERAN, \\ Anna Rosa SCALISE, Roberto SERAFINI, \\ Angelantonio SILVI \\ Geological Survey of Italy \\ Italian National Institute for Environmental Protection and Research \\ via Vitaliano Brancati 48, 00144 Rome, Italy
}

Ricevuto: 19 maggio 2016 / Accettato: 12 luglio 2016

Pubblicato online: 28 luglio 2016

This is an open access article under the CC BY-NC-ND license: http://creativecommons.org/licenses/by-nc-nd/4.0/

(C) Associazione Acque Sotterranee 2016 marnoso (Eocene superiore-Miocene superiore; permeabilità bassa); iv) complesso dei flysch (Miocene superiore; permeabilità bassa); v) complesso conglomeratico-sabbioso e detritico (Pliocene superiore-Pleistocene; permeabilità media); vi) complesso delle alluvioni (Quaternario; permeabilità bassa). Tra gli altri elementi riportati nella Carta principale vi sono: i limiti dei bacini e sottobacini idrografici, le stazioni di misura in alveo, le stazioni meteo climatiche, i settori interessati da scambi idrici tra acque superficiali e sotterranee, i limiti delle idrostrutture, la portata delle sorgenti puntuali e lineari, le direzioni di deflusso idrico sotterraneo. Inoltre, sono state realizzate Carte complementari a piccola scala a margine della Carta principale (es: Carta delle strutture idrogeologiche, Carta dei complessi idrogeologici rispetto ai valori dell'infiltrazione efficace, Sezioni idrogeologiche interpretative).

Abstract: The Geological Survey of Italy, Italian National Institute for Environmental Protection and Research is realizing the Sheet N.348 Antrodoco (Central Italy) of the Hydrogeological map of Italy as a cartographical test of the Italian hydrogeological survey and mapping guidelines, in the frame of the Italian Geological Cartography Project. The study area is characterized by structural units deeply involved in the Apennine Orogeny (Latium and Abruzzi region territory, Rieti and LAquila provinces) and including deposits of marine carbonate shelf, slope, basin and foredeep environments hosting relatively large amounts of groundwater resources. The map was realized to obtain the best possible representation of all bydrogeological elements deriving from field surveys, in order to characterize the bydrogeological asset. A control network for monthly measurement of surface and groundwater flow rates and hydrogeochemical parameters was performed. Data were uploaded in a geographic information system to perform the present preliminary bydrogeological cartography consisting in a main map showing the following hydrogeological complexes based on relative permeability degree (from bottom to top): i) calcareous (Jurassic-Cretaceous; high permeability); ii) calcareous-marly (Upper Cretaceous-Middle Eocene; intermediate permeability); iii) marly-calcareous and marly (Upper EoceneUpper Miocene; low permeability); iv) flysch (Upper Miocene; low permeability); v) conglomeratic-sandy and detritic (Upper PliocenePleistocene; intermediate permeability); vi) alluvial (Quaternary; low permeability). Among other elements shown in the main map there are bydrographical basin and sub-basin boundaries, stream ganging stations, meteo-climatic stations, streamwater-groundwater exchange processes, bydrostructure boundaries, point and linear spring flow rates, groundwater flow directions. Furthermore, complementary smaller-scale sketches at the margin of the main map were realized (e.g., bydrogeological structure map, hydrogeological complex map based on effective infiltration information, bydrogeological crosssections). 


\section{Introduction}

The Geological Survey of Italy of the Italian National Institute for Environmental Protection and Research (ISPRA) is realizing the new Geological map of Italy at 1:50,000 scale [CARtografia Geologica e geotematica d'Italia (CARG) Project]. This project includes hydrogeological mapping of the Italian territory. The CARG Project started in 1989 and specific guidelines for mapping survey and representation have been published in the collection SGN Quaderni, serie III, also dealing with map, explanatory notes and legend standard specifications for official geothematic mapping in Italy (e.g.: Servizio Geologico Nazionale 1995). In the CARG Project framework, the N.348 Antrodoco Sheet Project started and it was finalized to the realization, under direct investigation by the field geologists of the Geological Survey of Italy, of different cartographical products, including a hydrogeological map. In the sheet area, located between Lazio and Abruzzi regions (Central Apennine, Italy), mapping surveys (census and characterization) of the main hydrogeological elements have been conducted. The survey and representation activities for the realization of the hydrogeological Antrodoco Sheet Map have been conducted according to the cited guidelines (Servizio Geologico Nazionale 1995), also taking into account the recent modification and implementation proposals discussed after some experimental studies in test areas of the Italian territory (Scalise and Martarelli 2008). The collected hydrogeological information has been organized in a database in geographic information system (GIS) environment, which allowed the processing of graphical and mapping outcomes described in this paper regarding their main approaches and results. The regional hydrogeological features of Central Apennine, including the study area, are well known (e.g., Giuliano and Sciotti 1981; Celico 1983a, 1983b; Boni et al. 1986a, 1986b, 1995; Petitta 2009; Petitta et al. 2011; Capelli et al. 2012), but, differently to these papers, the present study have been conducted in a more detailed field survey scale $(1: 25,000)$. Therefore, the proposed hydrogeological reconstructions include springs (and other hydrogeological elements) with subordinate potentiality (e.g. cropping out at high elevation or within terrigenous terrains) but having great importance for local groundwater supply needs.

\section{Geological settings}

The study area is located in Central Italy, within the Apennine Belt, in a very complex geological-structural context characterized by superposition of tectonic units mainly verging SW to NE and $\mathrm{W}$ to $\mathrm{E}$. These units are composed of sedimentary successions deposited within different paleogeographical domains, from carbonate shelf to foredeep environments (Fig. 1). In the Antrodoco sheet, four main structural units occur (Fig. 1): M.Sibillini, Gran SassoCittareale, M.Giano-M.Gabbia and Acquasanta-Montagna dei Fiori (e.g.: Bigi et al. 1991). The two former units are separated each other by the Olevano-Antrodoco-Posta-M. Sibillini overthrust alignment (average trend N10-20 in this area), which is part of the Ancona-Anzio regional tectonic

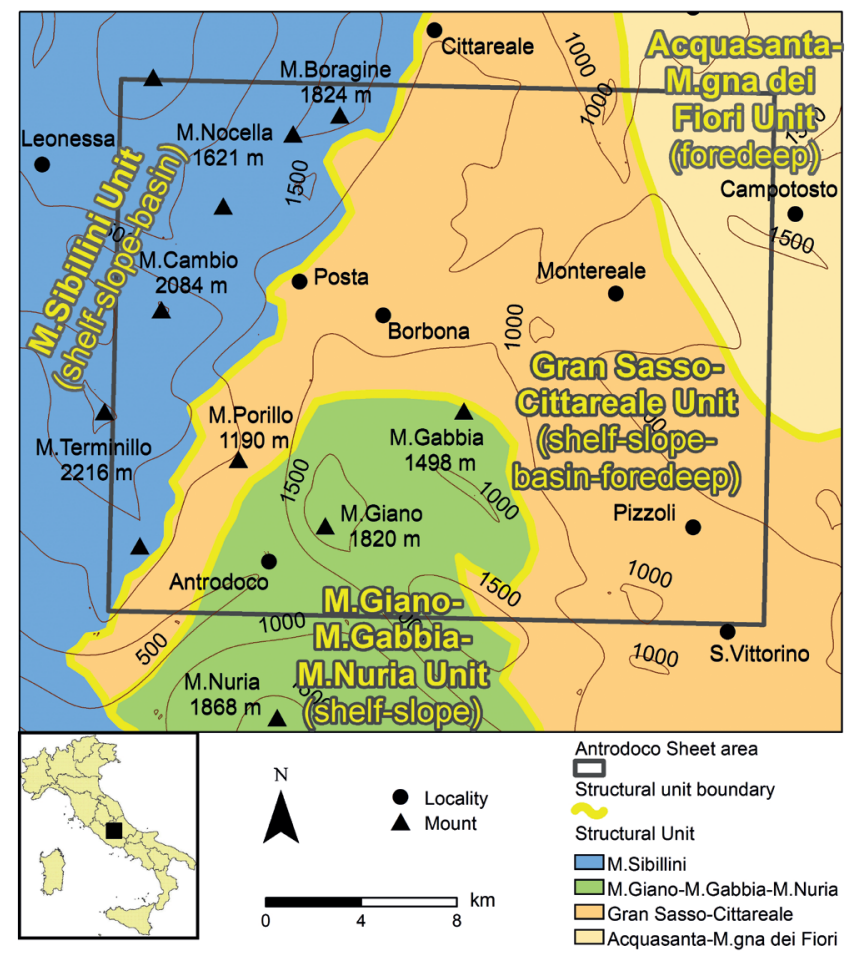

Fig. 1 - Structural sketch map of the Antrodoco Sheet area and surroundings. Location of the area within the Italian geographical context is also shown.

Fig. 1 - Schema strutturale dell'area del Foglio Antrodoco e dintorni. È stata anche evidenziata la posizione dell'area nell'ambito del territorio italiano.

alignment of the Authors. N-S trending reliefs with sharp morphologies and elevation reaching over $2000 \mathrm{~m}$ above sea level (a.s.l.) characterize the M.Sibillini structural unit. The cropping out terrains span from Calcare Massiccio (Lower Jurassic) to Marne con Cerrogna (Miocene) formations of the Umbro-Marchigiano-Sabina succession and its Cenozoic cover and are characterized by carbonate platform passing to slope and subordinately to marine basin environment deposits (e.g.: Bigi et al. 1991; Piana 1995).

The Gran Sasso-Cittareale domain defines a long relief with Apenninic (NW-SE) trend and elevation reaching about 1500 $\mathrm{m}$ a.s.l., constituting the westernmost sector of the Gran Sasso-M.S.Franco chain; in this area, towards the northern sectors, the pre-evaporitic terrigenous turbiditic deposits of the Laga Formation (Upper Miocene) also crop out on top of the succession previously defined. The normal fault with a NW-SE trend cropping next to Pizzoli town occurs in the SE part of the unit, along the transition towards the M.Giano-M. Gabbia domain (e.g.: Ghisetti and Vezzani 1988; Capotorti et al. 1991; Centamore et al. 1991; Piana 1995).

The M.Giano-M.Gabbia unit has an Apenninic (NW-SE) structural trend with maximum elevations of about 1800 $\mathrm{m}$ a.s.l. The depositional features are ascribed to a carbonate platform, with a succession similar to that of the LatiumAbruzzi succession (general interval from Upper Triassic to Paleogene), passing to a slope (Maiolica, Upper Jurassic-Lower Cretaceous, to Marne con Cerrogna, Miocene, formations) environment. The unit is bordered at $\mathrm{N}$ and $\mathrm{E}$ by the curve 
shaped overthrust M.Cagno-M.Gabbia and at SW by the normal fault with a NW-SE trend cropping next to Antrodoco town (e.g.: Capotorti et al. 1991, 1995a, 1995b; Centamore et al.1991; Piana 1995).

Reliefs with NW-SE trend and elevation reaching 1600 $\mathrm{m}$ a.s.l characterize the Acquasanta-Montagna dei Fiori structural domain. It crops out without evident tectonic discontinuity toward NE moving on from the Gran SassoCittareale unit. Terrigenous Tortonian-Messinian terrains (top part of Marne con Cerrogna, Marne con Pteropodi and Laga Flysch formations) crop out in this unit, which represents the evolution of the above said slope-basin successions towards a foredeep environment. The Olevano-Antrodoco-Posta-M. Sibillini tectonic alignment separates this unit from the M.Sibillini domain (e.g.: Ghisetti and Vezzani 1988; Capotorti et al. 1991; Centamore et al. 1991; Piana 1995).

\section{Overview of the research activities}

According to Italian official Guidelines to survey, informatization and mapping of hydrogeological data (Servizio Geologico Nazionale 1995) the following main survey and processing activities have been performed throughout a total sheet area of about $600 \mathrm{~km}^{2}$ : spring census (about 250); stream-gauging stations selection (about 45); definition of a monitoring network for monthly measurements during 2 years (about 70 springs and 10 stream stations); physical-chemical characterization of waters by in situ parameters (all water points) and chemical analyses (55 springs; Amanti et al. 2012); organization and realization of a hydrogeological GIS; study of hydraulic exchanges between groundwater and main stream waters; definition of hydrogeological complexes; definition of the main hydrostructural units and hydrogeological budget calculations; groundwater flow direction characterization; annual variations and relationships between precipitations and hydrogeological parameters of springs and streams.

All information about hydrogeological elements has been collected in a dedicated database that allows data migration towards GIS software. As a whole, different layers regarding each hydrogeological element were set; each layer was linked to attribute tables with element description, quantitative field survey measurements, available chemical analyses of waters, diagrams, pictures and so on.

The research activities about water sources (springs, wells), streams and waterways existing in the study area have been carried out in order to characterize the local hydrogeological asset. A periodic monitoring, aimed to the measurement of the water discharge and of some physicochemical parameters like temperature, $\mathrm{pH}$ and conductivity, has been conducted. Flow measurements in sequential (interval about $2 \mathrm{~km}$ ) gauging stations along the main rivers and of their main tributary streams have been made as well.

This latter activity allowed collecting sequential discharge measurement in order to depict the streamwater-groundwater exchange balance along the main river courses, evidencing that the Velino River has discontinuous draining sectors (about 50 $\mathrm{L} / \mathrm{s}$ per linear $\mathrm{km}$ ) in the up-hill of the hydrographical basin and discontinuous dispersing sectors (about $100 \mathrm{~L} / \mathrm{s}$ per linear $\mathrm{km}$ ) in the mid and low-hill of the Antrodoco sheet area. The Ratto River mainly drains relatively low values of the groundwater along its course (about 2-5 to $10-15 \mathrm{~L} / \mathrm{s}$ per linear $\mathrm{km})$. The Aterno River has discontinuous draining sectors (about $25 \mathrm{~L} / \mathrm{s}$ per linear $\mathrm{km}$ ), but also local sectors where high water amounts are dispersed (about 50-150 L/s per linear $\mathrm{km}$ ). This balance calculation allowed recognizing linear spring (groundwater contribution to surface waters) occurrence, which has then been represented in the map.

Furthermore, the Velino, Ratto and Aterno rivers have usually perennial regime, except for the up-hill sector of the Ratto River, the sector between Sigillo Village and Antrodoco Town of the Velino River, which is interested by huge derivations for hydroelectric purposes, and the sector before the L'Aquila Town of the Aterno River, which is seasonally dry.

\section{Materials and Methods Hydrogeological complexes}

The study area cropping out terrains have been distinguished into hydrogeological complexes because of their relative permeability and considering hydrogeological features as well (according to Servizio Geologico Nazionale 1995). Spatial dimension and continuity, hydraulic productivity and fissuration status of the constituting lithologies have been as well considered for hydrogeological complex classification. Lithologies characterized by very low permeability (basal aquiclude; e.g., Marne a Fucoidi, clayey Corniola and Marne di Monte Serrone) and the associated high permeability lithotypes (aquifer) in direct stratigraphical sequence have been included in the same complex in order to avoid a not useful existence of too many complexes in the hydrogeological legend.

The distinguished complexes are, from top to bottom (annual mean effective infiltration values are from Boni et al. 1986a, 1995), in the following list.

\section{Alluvial complex (Quaternary)}

It includes alternating clay, silt, sand and gravel with peat. Total thickness is from few to about $100 \mathrm{~m}$. It includes also the lower deposits of the lacustrine basins, the pedogenized volcanic tuffs and the red soils. It may host variable potentiality aquifers. The effective infiltration is generally low. Relative permeability degree is scarce.

\section{Sandy-conglomeratic and detritical complex (Upper Pliocene- Pleistocene)}

It includes cemented and stratified polygenic conglomerate, sand and sandy clay and conoid and slope deposits, sometimes cemented. Total thickness up to some hundreds meters. It may host local relevance aquifers. Effective infiltration is variable from 300 to $500 \mathrm{~mm} / \mathrm{a}$. Relative permeability degree is intermediate.

\section{Flysch complex (Upper Miocene p.p.)}

It is composed of arenaceous, arenaceous-pelitic and peliticarenaceous pre-evaporitic deposits of the Laga formation. Total thickness is about $1500 \mathrm{~m}$. It may host perched aquifer 
of local importance within the most permeable horizons. Effective infiltration is generally lower than $200 \mathrm{~mm} / \mathrm{a}$ concerning the most permeable terrains. Relative permeability degree is scarce.

\section{Marly-calcareous and marly complex (Upper Eocene-Upper Miocene p.p.)}

It consists of detritical marl and marly limestone (Scaglia cinerea), marly limestone and calcareous marl (Bisciaro), marl, calcareous marl and calcarenite (Marne con Cerrogna, Marne ad Orbulina). Total thickness is $300-500 \mathrm{~m}$. The most permeable lithologies may host small aquifers with local importance, while the marly formations have a very low permeability. Effective infiltration is variable from 200 to 300 $\mathrm{mm} / \mathrm{a}$, but is less than $200 \mathrm{~mm} / \mathrm{a}$ regarding marly lithologies. Relative permeability degree is scarce.

Calcareous-marly complex (Middle Cretaceous-Middle Eocene)

It is composed of marl with limestone and cherty marly limestone showing a low permeability (Marne a Fucoidi, evidenced in the map with a dense hatching), cherty marly limestone (Scaglia Bianca and Scaglia Rossa) and detritical limestone and breccias with rudists (Calcari a Rudiste). Total thickness is $250-400 \mathrm{~m}$. It may host local importance aquifers, often perched on the marly terrains. Effective infiltration is between 500 and $600 \mathrm{~mm} / \mathrm{a}$ regarding the carbonatic lithologies, but marly terrains show lower values. Relative permeability degree is intermediate.

Upper calcareous complex (Middle Jurassic-Lower Cretaceous) It includes: i) marl and marly limestone, sometimes with chert, with a relatively low permeability, scarce fissuration degree, generally acting as an aquiclude (argillaceous Upper Corniola, Marne del Monte Serrone, Calcari and Marne a Posidonia, Calcari diasprigni); ii) fine grained stratified

limestone with high secondary permeability due to fissuration and subordinately to karst processes and hosting perched aquifers (Maiolica). In the M.Giano-M.Gabbia hydrostructure, the formations belonging to the i) succession of this complex are condensed, actually causing a hydraulic continuity with the underlying complex. Total thickness is from 450 to 750 $\mathrm{m}$. Effective infiltration is generally more than $600 \mathrm{~mm} / \mathrm{a}$ in carbonate lithologies, where it may attain $800-900 \mathrm{~mm} / \mathrm{a}$. Relative permeability degree is high.

\section{Basal calcareous complex (Lower Jurassic-Upper Cretaceous)}

It is composed of calcareous formations with high secondary permeability due to both fissuration and karst processes. Thickness is variable from 550 to $750 \mathrm{~m}$ in the Umbro-Sabina facies (Lower Jurassic; W sector of the map) and up to 2000 $\mathrm{m}$ in the active calcareous marine shelf (Lower Jurassic-Upper Cretaceous), where this complex is actually in hydraulic continuity with the overlying complex. It hosts a regional basal main aquifer with a high productivity at the stratigraphical levels of Calcare Massiccio and lower part of Corniola formations (Umbro-Sabina facies) and of Dolomie a calcari dolomitici formation (carbonatic shelf facies; Lower Jurassic). Effective infiltration is more than $600 \mathrm{~mm} / \mathrm{a}$, but it may attain $800-1000 \mathrm{~mm} / \mathrm{a}$. Relative permeability degree is high.

\section{Dolomitic complex (Upper Triassic-Lower Jurassic)}

It includes: i) massive dolostone with evaporitic layers at the lower stratigraphic levels (Dolomia Principale; Upper Triassic; apparent thickness about $150 \mathrm{~m}$ ) representing the basal aquiclude of the regional hydrogeological system; ii) calcareousdolomitic deposits (Lower Jurassic; thickness about 200-400 $\mathrm{m}$ ); iii) calcareous dolomitic horizons due to dolomitization processes of the Calcare Massiccio and/or Corniola formations (Lower Jurassic). ii) and iii) generally act as an aquiclude of local hydrogeological systems. This complex may sometimes display an intermediate degree of relative permeability due to tectonic and subordinately karst processes, as well with formation of variable potentiality local aquifers. Effective infiltration is generally lower than $200 \mathrm{~mm} / \mathrm{a}$, but it may attain 200-400 $\mathrm{mm} / \mathrm{a}$ due to secondary permeability. Relative permeability degree is very low.

\section{Results and Discussion}

The GIS software allowed performing mapping elaborations, starting with preparation of a symbol legend according to the Italian guidelines indications. The selected symbology for Surface hydrology elements includes: hydrographical basins; water streams (stream flow typology, discharge, base flow, groundwater-streamwater exchange); gauging stations. Regarding streams, the proposed symbology put into evidence a generic symbol for stream flow regime and, in the sectors where information is available, the mean discharge with a violet line overlapped by base flow line in blue, both with graduated linear symbols, in order to show flow regime variations. Information about groundwater seepage to surface water flow or vice versa is given as well (Fig. 2).

As far as groundwater hydrology elements (hydrogeological boundaries; point and linear springs: discharge, electrical conductivity; groundwater flow directions) are concerned, the proposed symbology for springs put into evidence the mean discharge with graduated symbols in blue and, for springs, this symbol is overlapped and centered by electrical conductivity symbol in graduated color, in order to evidence the spatial distribution of this significant parameter (Fig. 3). In addition, the electrical conductivity distribution of the springs throughout the Antrodoco sheet area, excluding the few sulfuric/sulfate water springs, evidences different sectors where springs having values mainly within the lowintermediate $(228-460 \mu \mathrm{S} / \mathrm{cm})$ or intermediate-high (350$880 \mu \mathrm{S} / \mathrm{cm}$ ) range classes here defined occur. Since the former interval is typical of springs occurring within the calcareous to marly deposits and the latter of springs in the flysch deposits, it will be possible to use these features to contribute to define the hydrogeological structures in detail. Furthermore, it is worthy of note that the discharge has generally low values $(<10 \mathrm{~L} / \mathrm{s})$ except for the piedmont and down-valley springs that may reach 10-100 L/s and one spring which reaches few hundreds $\mathrm{L} / \mathrm{s}$.

Artificial works (waterworks: water supply, water wells; hydraulic works), karst areas and geological elements of hydrogeological interest were as well included 
SURFACE HYDROLOGY

\section{CATCHMENT BASIN BOUNDARY}
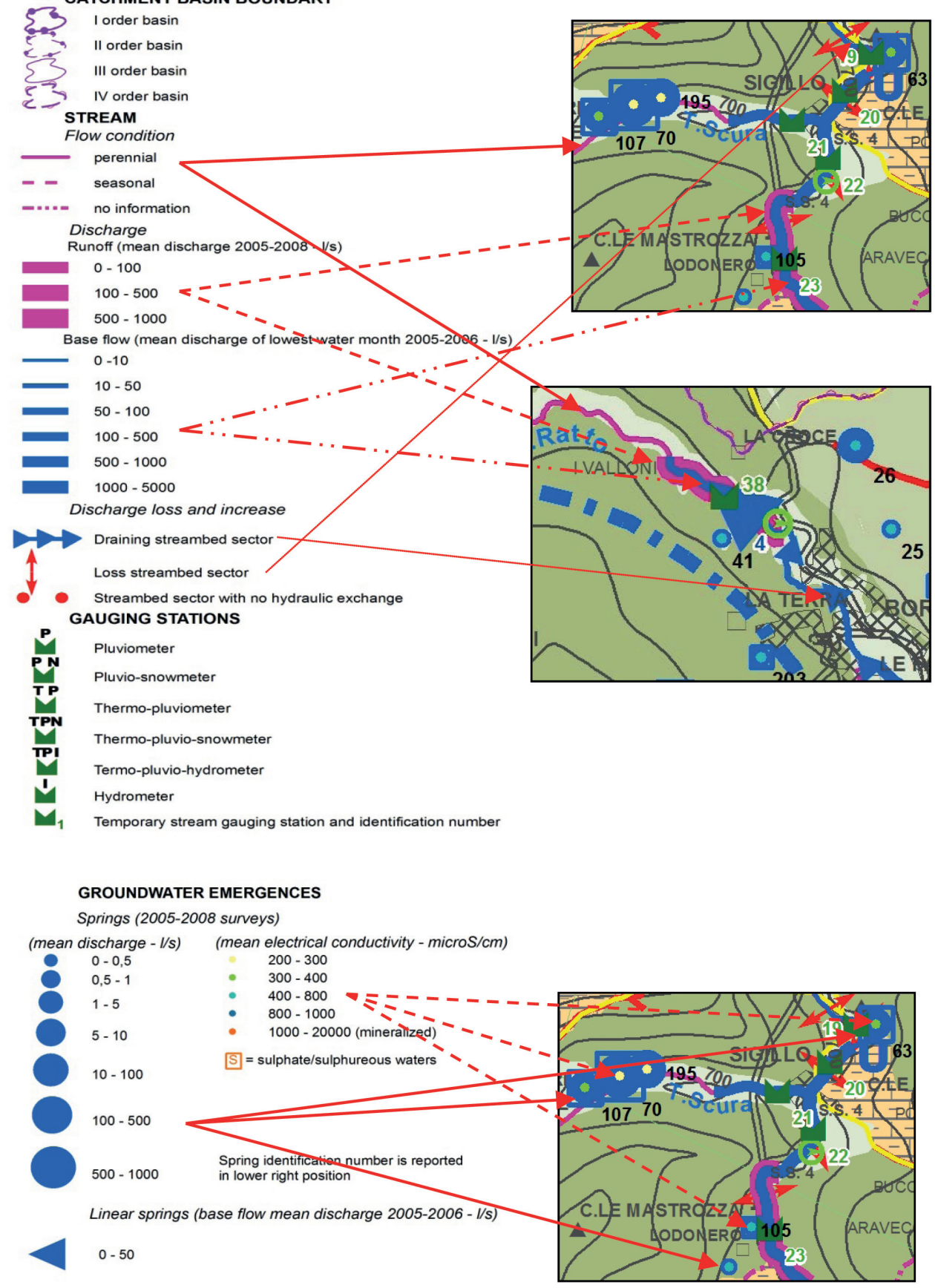

$50-100$

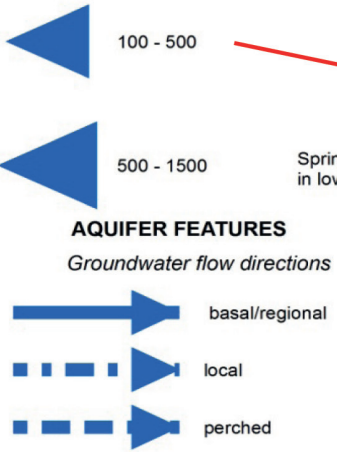

Fig. 2 - Part of the symbol legend dedicated to surface bydrology elements. The proposed symbology for streams evidences stream flow regime, mean discharge and base flow discharge. Groundwater to surface water flow or vice versa is shown as well.

Fig. 2 - Settore della legenda dei simboli dedicato all'idrologia superficiale. La simbologia proposta per i corsi d'acqua evidenzia il regime del flusso idrico, la portata media e la portata del flusso di base. È anche rappresentato lo scambio idrico dalle acque sotterranee a quelle di superficie e viceversa.
Fig. 3 - Part of the symbol legend dedicated to groundwater hydrology elements. The proposed symbology for springs puts into evidence the mean discharge and, for springs, the electrical conductivity values as well.

Fig. 3 - Settore della legenda dei simboli dedicato all'idrologia sotterranea. La simbologia proposta per le sorgenti evidenzia la portata media e, per le sorgenti, anche i valori della conducibilità elettrica. 
in the Legend (Fig. 4).

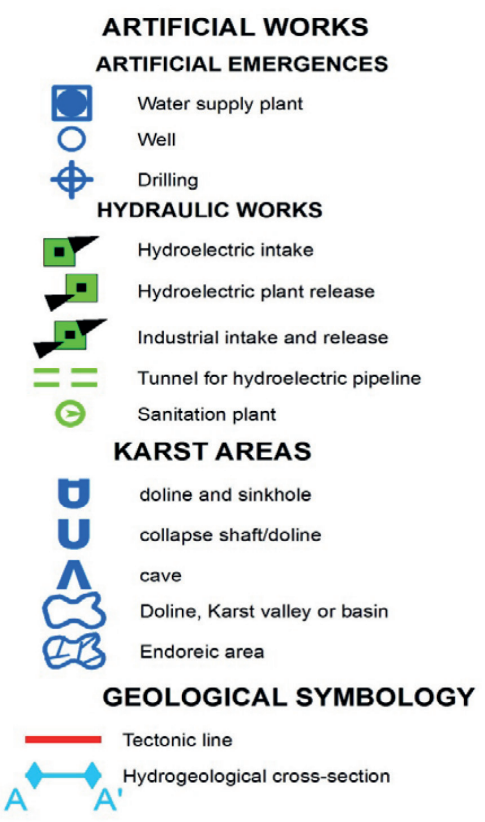

Fig. 4 - Part of the symbol legend dedicated to artificial works, karst areas and geological elements of hydrogeological interest.

Fig. 4 - Settore della legenda dei simboli dedicato alle opere artificiali, alle aree carsiche e agli elementi geologici di interesse idrogeologico.
Mapping processing for hydrogeological complexes definition have also been performed and colors and lithological patterns have been assigned to four relative permeability degrees in order to give immediate clear information on hydrogeological role of each complex (Fig. 5). In detail, high and intermediate relative permeability complexes have overlapping lithological patterns and are represented with red-orange and yelloworange shades of colors in order to evidence their roles of recharge areas and considerable potentiality aquifers, respectively. On the contrary, scarce and very low relative permeability complexes have no lithological patterns and green-grayish and gray shades of colors, in order to evidence their roles of aquitard (or subordinate potentiality aquifer) and aquiclude, respectively.

Hydrogeological vertical cross-sections have been realized using quite different representation criteria, with respect to those adopted in the map, for high and intermediate relative permeability degree complexes. Indeed, the corresponding polygons have been represented by using only a lithological pattern with the same map complex color and without any background color, in order to give the best visibility to the saturated portion of the distinguished aquifers, represented in blue shades of color (Fig. 6).

The map is also set with small-scale sketches showing effective infiltration of hydrostructures, and meteoclimatic station network, air temperature and rainfall spatial distribution (Figs. 7 and 8).

Finally, an overview of the Hydrogeological map is given in Fig. 9.

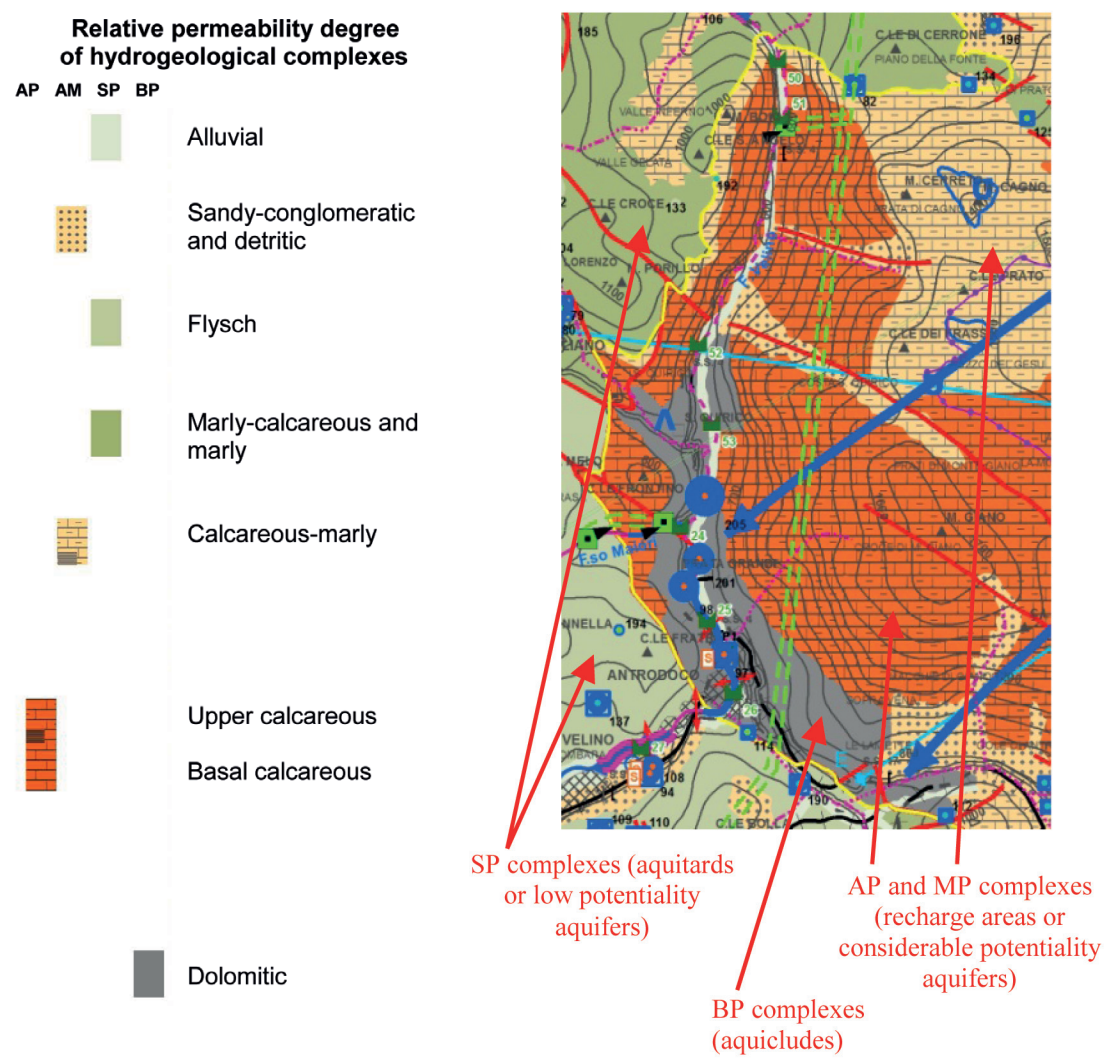

Fig. 5 - Sketch of the hydrogeological complex legend. High (AP) and intermediate (MP) relative permeability complexes have overlapping lithological patterns and are represented by red-orange and yellow-orange shades of colors, respectively. Scarce $(S P)$ and very low $(B P)$ relative permeability complexes have no lithological patterns and green-grayish and gray shades of colors, respectively.

Fig. 5 - Schema della legenda dei complessi idrogeologici. I complessi aventi alta (AP) e media (MP) permeabilità relativa hanno sovrassegni litologici e sono rappresentati in tonalità di colore, rispettivamente, rosso-arancio e giallo-arancio. I complessi aventi scarsa (SP) e bassissima (BP) permeabilità relativa non hanno sovrassegni litologici e hanno tonalità di colore, rispettivamente, grigioverdi e grigie. 

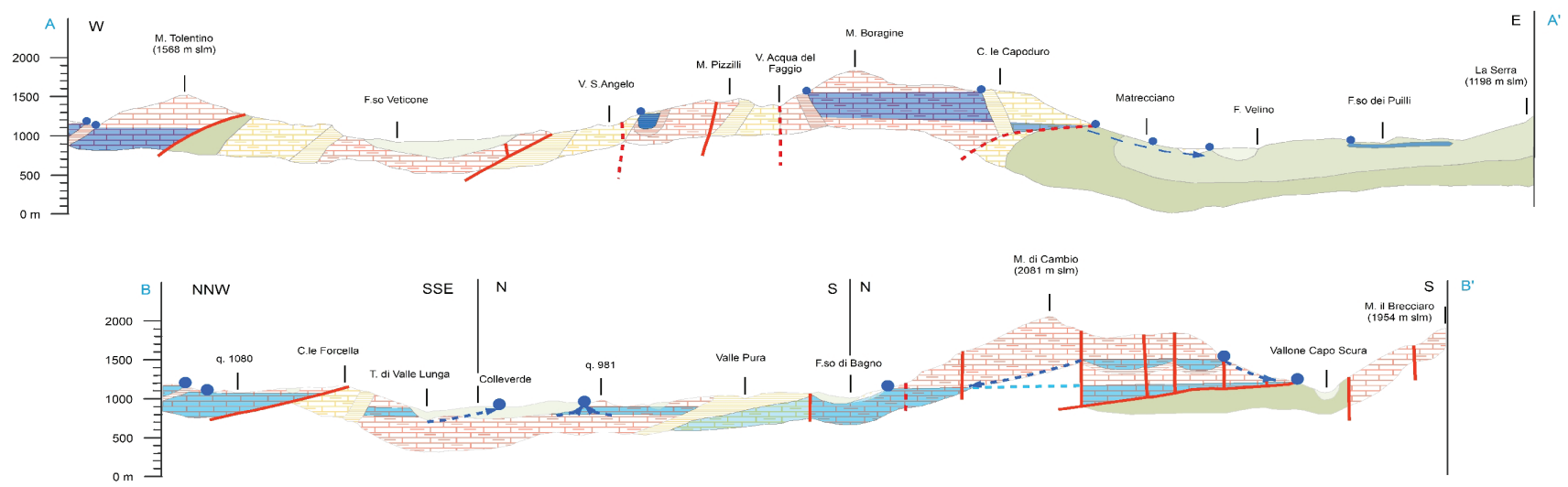

Fig. 6 - Examples of hydrogeological vertical cross-sections (trace locations are shown in Fig. 9). High and intermediate relative permeability degree hydrogeological complexes are represented using only a lithological pattern with the same map complex color and without any background color in order to give the best visibility to the distinguished aquifers (in blue shades of color).

Fig. 6 - Esempi di sezioni idrogeologiche interpretative (le tracce di sezione sono riportate in Fig. 9). I complessi idrogeologici aventi grado di permeabilità relativo alto e medio sono rappresentati solo con un retino litologico dello stesso colore del poligono in carta, per dare maggiore visibilità agli acquiferi distinti, riportati con differenti tonalità di colore blu.

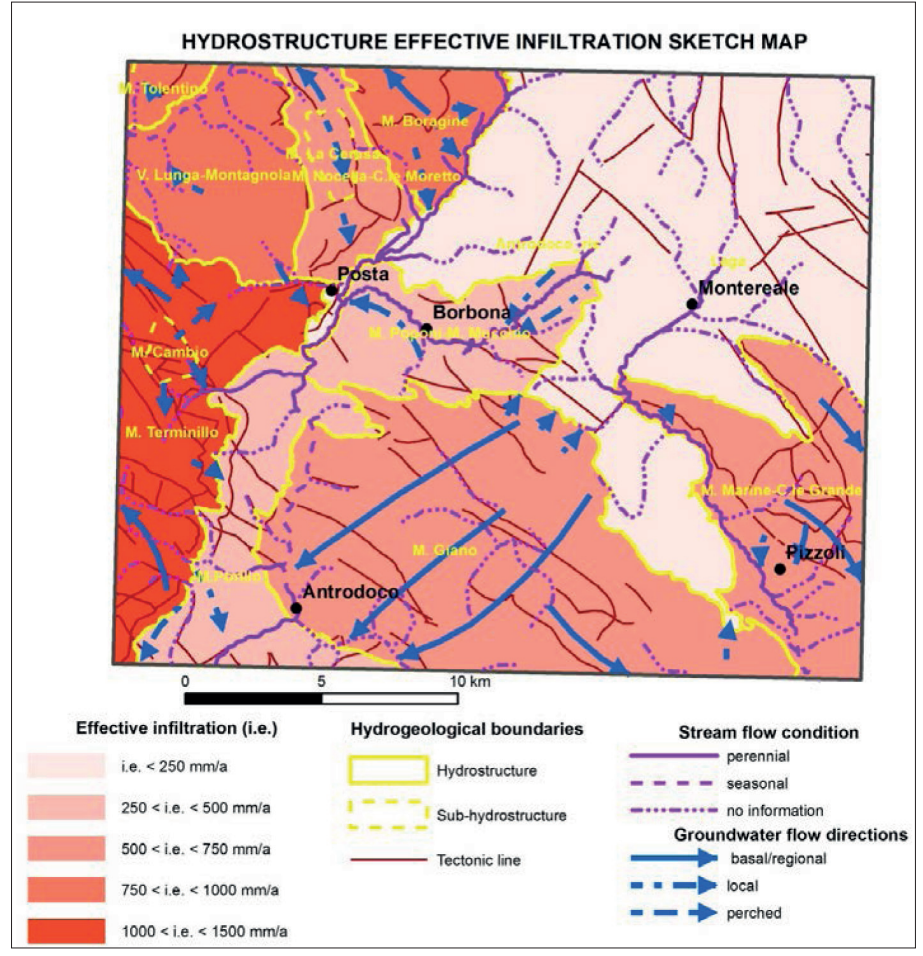

Fig. 7 - Small-scale sketch showing effective infiltration of hydrostructures.

Fig. 7 - Schema a piccola scala dell'infiltrazione efficace delle idrostrutture.

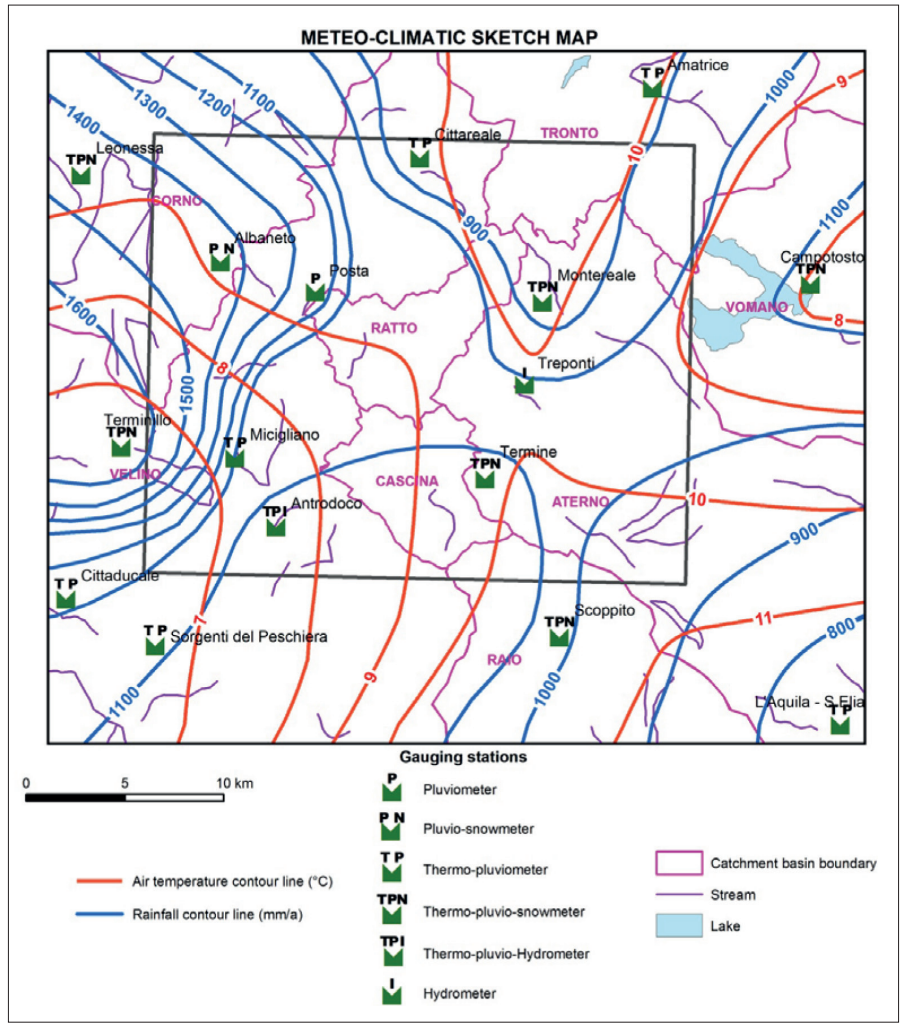

Fig. 8 - Small-scale sketch showing meteo-climatic station network, and air temperatureand rainfall spatial distribution.

Fig. 8 - Schema a piccola scala delle stazioni meteoclimatiche e della distribuzione spaziale delle temperature e delle precipitazioni. 

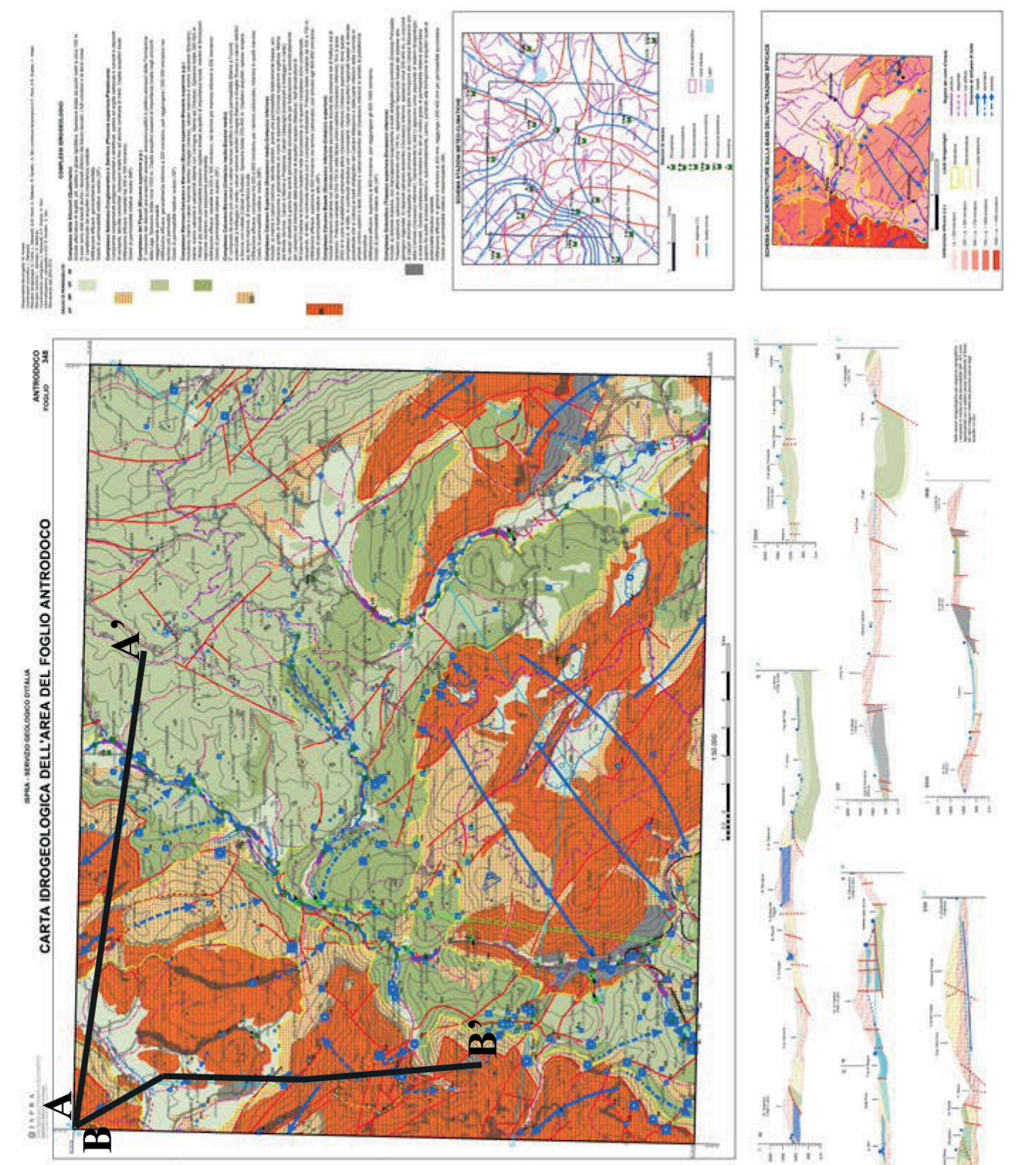

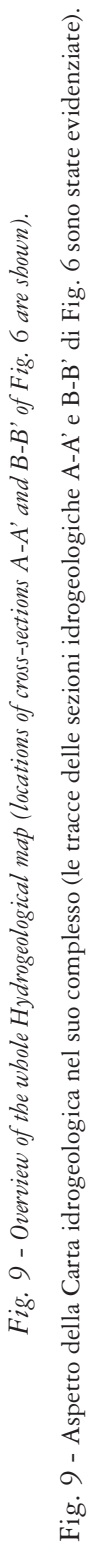

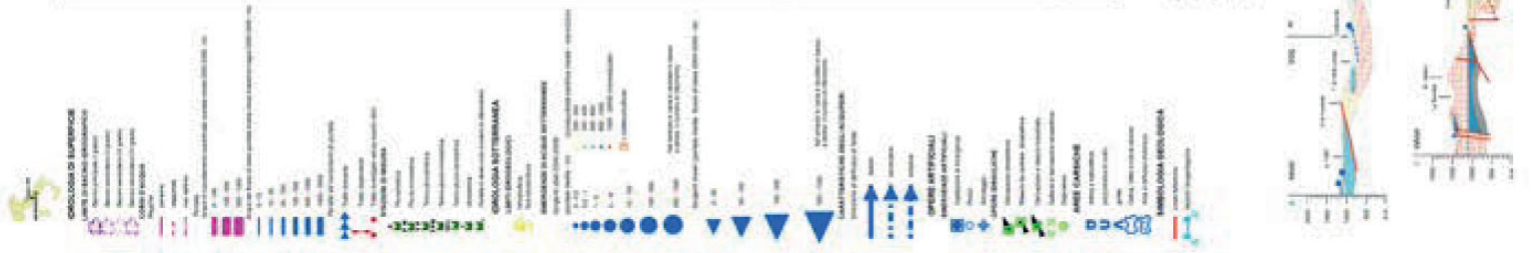




\section{Conclusions}

The Geological Survey of Italy of ISPRA is realizing the new Geological Map of Italy at 1:50,000 scale (CARG Project) that includes hydrogeological mapping of the Italian territory. In this framework, the N.348 Antrodoco Sheet Project started; it was finalized also to the realization of the hydrogeological map.

The study area is located in Central Italy, within the Apennine Belt, in a very complex geological-structural context characterized by superposition of tectonic units mainly verging SW to NE and W to E. Four main structural units, composed of sedimentary successions deposited within different paleogeographical domains from carbonate shelf to foredeep environments, occur in the Antrodoco sheet: the M.Sibillini, the Gran Sasso-Cittareale, the M.Giano-M. Gabbia and the Acquasanta-Montagna dei Fiori units.

According to Italian official hydrogeological mapping guidelines (Servizio Geologico Nazionale 1995) the following main survey and processing activities have been performed: spring census; stream-gauging stations selection; definition of a monitoring network for monthly measurements during 2 years; physico-chemical characterization of waters; realization of a hydrogeological GIS; definition of hydrogeological complexes; definition of the main hydrostructural units and hydrogeological budget calculations; groundwater flow direction characterization. A periodic monitoring (discharge, temperature, $\mathrm{pH}$ and conductivity) was started.

Flow measurements in sequential gauging stations along the main streams allowed depicting the streamwater-groundwater exchange balance and recognizing linear spring (groundwater contribution to surface waters) occurrences.

The study area cropping out terrains have been distinguished in hydrogeological complexes on the basis of their relative permeability.

The distinguished hydrogeological complexes are (from top to bottom): i) alluvial complex (effective infiltration generally low; relative permeability degree is scarce); ii) sandyconglomeratic and detritic complex (it hosts local relevance aquifers; effective infiltration from 300 to $500 \mathrm{~mm} / \mathrm{a}$; relative permeability degree is intermediate); iii) flysch complex (it hosts local importance aquifer; effective infiltration is lower than 200 $\mathrm{mm} / \mathrm{a}$; relative permeability degree is scarce); iv) marlycalcareous and marly complex (it hosts local importance aquifers; effective infiltration from 200 to $300 \mathrm{~mm} / \mathrm{a}$; relative permeability degree is scarce); v) calcareous-marly complex (it hosts local importance aquifers; effective infiltration 500-600 $\mathrm{mm} / \mathrm{a}$; relative permeability degree is intermediate); vi) upper calcareous complex (effective infiltration 800-900 mm/a; relative permeability degree is high); vii) basal calcareous complex (it hosts a high productivity regional basal aquifer; effective infiltration $800-1000 \mathrm{~mm} / \mathrm{a}$; relative permeability degree is high); viii) dolomitic complex (it represents the basal aquiclude of regional and local hydrogeological system; effective infiltration lower than $200 \mathrm{~mm} / \mathrm{a}$; relative permeability degree is very low).

The GIS software allowed performing mapping elaborations and preparation of a symbol legend according to the Italian guidelines indications. As concerns the surface hydrology elements, the proposed symbology for streams put into evidence a generic symbol for stream flow regime and, in the sectors were information is available, the mean discharge with a violet line overlapped by base flow line in blue, in order to show flow regime variations. Information about groundwater to surface water flow or vice versa is provided as well. Discussing groundwater hydrology elements, the proposed symbology for springs put into evidence the mean discharge and, for springs, this symbol is overlapped and centered by the electrical conductivity symbol in order to evidence the spatial distribution of this significant parameter.

The legend includes also artificial works (waterworks: water supply, water wells; hydraulic works), karst areas and geological elements of hydrogeological interest.

As for the hydrogeological complex legend, colors and lithological patterns have been assigned to four relative permeability degrees in order to give immediate clear information on the hydrogeological role of each complex.

Furthermore, hydrogeological vertical cross-sections have been realized in order to give the best visibility to the distinguished aquifers.

The map is also set with small-scale sketches showing effective infiltration of hydrostructures and meteo-climatic station network, air temperature and rainfall spatial distribution.

Finally, the carried out activities are contributing to: i) national hydrogeological mapping guidelines testing and implementation; ii) technical-scientific experimentation and research on best practice of hydrogeological mapping; iii) improvement of the project for the realization of the Hydrogeological map of Italy within the CARG Project; iiii) support to groundwater resource management actions.

Acknowledgments: two anonymous referees are kindly acknowledged for their useful comments and suggestions. 


\section{REFERENCES}

Amanti M., Buchetti M., Centioli D., Conte G., Flammini D., Martarelli L., Monti G.M., Motteran G., Pati A., Silvi A. (2012). Hydrogeochemical features of spring waters in the Sheet N.348 "Antrodoco" area. Per. Mineral. 81: 269-299.

Bigi S., Calamita F., Centamore E., Deiana G., Ridolfi M., Salvucci R. (1991). Assetto strutturale e cronologia della deformazione della "zona d'incontro" tra le aree umbro-marchigiana e laziale-abruzzese (Marche meridionali e Lazio-Abruzzo settentrionali) "Structural asset and deformation chronology of the zone between Umbro-Marchean and Latium-Abruzzi areas (Southern Marche and Northern Latium-Abruzzi". Studi Geologici Camerti vol. spec. 1991/2: 21-26.

Boni C.F., Bono P., Capelli G. (1986a). Schema idrogeologico dell'Italia centrale "Hydrogeological outline of Central Italy". Mem. Soc. Geol. It., 35: 991-1012.

Boni C.F., Bono P., Capelli G., Lombardi S., Zuppi G.M. (1986b). Contributo all'idrogeologia dell'Italia centrale: analisi critica e metodi di ricerca "Contribution to the hydrogeology of Central Italy: critical analisis and research criteria". Mem. Soc. Geol. It., 35: 947-956.

Boni C.F., Capelli G., Petitta M. (1995). Carta idrogeologica dell'alta e media valle del Fiume Velino "Hydrogeological map of the high and middle Velino River Valley". Dip.to Scienze della Terra Univ. degli Studi di Roma La Sapienza - Dip.to Scienze Geologiche Univ. degli Studi di RomaTre - Comunità Montana del Velino-VI Zona (PostaRieti).

Capelli G., Mastrorillo L., Mazza R., Petitta M., Baldoni T., Banzato F., Cascone D., Di Salvo C., La Vigna F., Taviani S., Teoli P. (2012). Carta Idrogeologica del territorio della Regione Lazio scala 1:100.000. Carta delle unità idrogeologiche della Regione Lazio scala 1:250.000 "Hydrogeological Map of latium Region 1:100,000 scale. Hydrogeological Unit Map of Latium region 1:250,000 scale". Sapienza Università di Roma - Università Roma Tre, S.EL.C.A. Firenze.

Capotorti F., Centamore E., Chiocchini M., Civitelli G., Corda L., Mancinelli A., Mariotti G., Romano A., Salvucci R. (1991). Dati preliminari geologico-stratigrafici sull'Unità di Monte Giano e Monte Gabbia "Preliminary geological-stratigraphical data about Monte Giano and Monte Gabbia Unit". Studi Geologici Camerti, vol. spec. 1991/2: 119-123.

Capotorti F., Fumanti F., Mariotti G. (1995a). Carta geologica del settore compreso tra il M. Nuria, il M. Gabbia e l'alta valle del Fiume Velino (Appennino centrale) - Scala 1:50.000 "Geological Map of the area included among M.Nuria, M.Gabbia and the Velino River High Valley (Central Apennine)". Studio Faro, Roma.

Capotorti F., Fumanti F., Mariotti G. (1995b). Evoluzione tettonicosedimentaria e strutturazione del settore di piattaforma carbonatica laziale-abruzzese nell'alta Valle del F. Velino "Tectonical-sedimentary evolution and outline of the Latium-Abruzzi carbonatic shelf in the Velino River Valley”. Studi Geologici Camerti, vol. spec. 1995/2: 101-111.
Celico P.B. (1983a). Carta Idrogeologica dell'Italia centro-meridionale alla scala 1:400.000 "Hydrogeological map of Central-southern Italy at 1:400,000 scale". Cassa per il Mezzogiorno, Roma.

Celico P.B. (1983b). Idrogeologia dei massicci carbonatici, delle piane e delle aree vulcaniche dell'Italia centro-meridionale "Hydrogeology of carbonate reliefs, plains and volcanic areas of Central-southern Italy". Quaderni della Cassa per il Mezzogiorno, 4(2), 225 pp.

Centamore E., Civitelli G., Corda L., Mariotti G. Romano A., Capotorti F., Salvucci R. (1991). Carta geologica dell'area di M. Giano-M. Gabbia-Gole del Velino (Alta valle del F. Velino, Lazio nord-orientale) - Scala 1:25.000 "Geological Map of the M. Giano-M.GabbiaVelino Gorge area (Velino River High Valley, North-Eastern Latium) - 1:25,000 scale". ESSE GI ESSE, Roma.

Ghisetti F., Vezzani L. (1988). Rapporti strutturali tra il fronte del Gran Sasso ed il Flysch della Laga (Appennino centrale) "Structural relationships between the Gran Sasso overthrust and the Laga Flysh (Central Apennine)". Mem. Soc. Geol. It., 41: 1171-1178.

Giuliano G., Sciotti M. (1981). Schema idrogeologico del Bacino del Tevere "Hydrogeological outline of Tiber Basin". Quad. Ist. Ric. Acque, 48, 67 pp., Consiglio Nazionale delle Ricerche, Roma.

Petitta M. (2009). Idrogeologia della media valle del Fiume Velino e della Piana di S.Vittorino Rieti, Italia Centrale) "Hydrogeology of the middle valley of Velino River and S.Vittorino Plain (Rieti, Central Italy)". Italian Journal of Engineering Geology and Environment, 1: 157-181.

Petitta M., Primavera P., Tuccimei P., Aravena R. (2011). Interaction between deep and shallow groundwater systems in areas affected by Quaternary tectonics (Central Italy): A geochemical and isotope approach, Environmental Earth Sciences, 63:11-30, doi:10.1007/ s12665-010-0663-7.

Piana F. (1995). Caratteri geologico-strutturali della zona di M. Gabbia tra le Valli Velino ed Aterno (Appennino centrale, zona di raccordo tra i sovrascorrimenti del Gran Sasso e dei M. Sibillini) "Structuralgeological features of the Gabbia Mt area between Velino and Aterno rivers (Central Apennine, connection zone between Gran Sasso and Sibillini Mts overthrusts)". Studi Geologici Camerti, vol. spec. 1995/2: 375-385.

Scalise A.R., Martarelli L. (eds.) (2008). Studi sperimentali finalizzati alla cartografia idrogeologica "Field surveys for the implementation of hydrogeological cartography". Mem. Descr. della Carta Geol. d'It. LXXXI, $176 \mathrm{pp}$.

Servizio Geologico Nazionale (1995). Carta Idrogeologica d'Italia 1:50.000. Guida al rilevamento e alla rappresentazione "Hydrogeological Map of Italy - 1:50,000 scale. Guideline to survey and mapping". SGN Quaderni, serie III, N.5, IPZS. 